\title{
Hourly Electricity Prices in Day-Ahead Markets
}

\author{
Ronald Huisman, Christian Huurman and Ronald Mahieu
}

\begin{tabular}{|l|l|}
\hline \multicolumn{2}{|l|}{ ERIM REPORT SERIES RESEARCH IN MANAGEMENT } \\
\hline ERIM Report Series reference number & ERS-2007-002-F\&A \\
\hline Publication & January 2007 \\
\hline Number of pages & 13 \\
\hline Persistent paper URL & \\
\hline Email address corresponding author & rhuisman@rsm.nl \\
\hline Address & Erasmus Research Institute of Management (ERIM) \\
& RSM Erasmus University / Erasmus School of Economics \\
& Erasmus Universiteit Rotterdam \\
& P.O.Box 1738 \\
& 3000 DR Rotterdam, The Netherlands \\
& Phone: + 31104081182 \\
& Fax: $\quad+31104089640$ \\
& Email: info@erim.eur.nl \\
& Internet: $\quad$ www.erim.eur.nl \\
\hline
\end{tabular}

Bibliographic data and classifications of all the ERIM reports are also available on the ERIM website: www.erim.eur.nl 


\section{ERASMUS RESEARCH INSTITUTE OF MANAGEMENT}

\section{REPORT SERIES}

\section{RESEARCH IN MANAGEMENT}

\begin{tabular}{|c|c|}
\hline \multicolumn{2}{|c|}{ ABSTRACT AND KEYWORDS } \\
\hline Abstract & $\begin{array}{l}\text { This paper focuses on the characteristics of hourly electricity prices in day-ahead markets. In } \\
\text { these markets, quotes for day-ahead delivery of electricity are submitted simultaneously for all } \\
\text { hours in the next day. The same information set is used for quoting all hours of the day. The } \\
\text { dynamics of hourly electricity prices does not behave as a time series process. Instead, these } \\
\text { prices should be treated as a panel in which the prices of } 24 \text { cross-sectional hours vary from day } \\
\text { to day. This paper introduces a panel model for hourly electricity prices in day-ahead markets } \\
\text { and examines their characteristics. The results show that hourly electricity prices exhibit hourly } \\
\text { specific mean-reversion and that they oscillate around an hourly specific mean price level. } \\
\text { Furthermore, a block structured cross-sectional correlation pattern between the hours is } \\
\text { apparent. }\end{array}$ \\
\hline Free Keywords & Energy markets, Day-ahead electricity, Electricity prices, Panel models \\
\hline Availability & $\begin{array}{l}\text { The ERIM Report Series is distributed through the following platforms: } \\
\text { Academic Repository at Erasmus University (DEAR), DEAR ERIM Series Portal } \\
\text { Social Science Research Network (SSRN), SSRN ERIM Series Webpage } \\
\text { Research Papers in Economics (REPEC), REPEC ERIM Series Webpage }\end{array}$ \\
\hline Classifications & $\begin{array}{l}\text { The electronic versions of the papers in the ERIM report Series contain bibliographic metadata } \\
\text { by the following classification systems: } \\
\text { Library of Congress Classification, (LCC) LCC Webpage } \\
\text { Journal of Economic Literature, (JEL), JEL Webpage } \\
\text { ACM Computing Classification System CCS Webpage } \\
\text { Inspec Classification scheme (ICS), ICS Webpage }\end{array}$ \\
\hline
\end{tabular}




\title{
Hourly Electricity Prices in Day-Ahead MARKeTS
}

\author{
Ronald Huisman, Christian Huurman and Ronald Mahieu
}

June 2006

\begin{abstract}
This paper focuses on the characteristics of hourly electricity prices in day-ahead markets. In these markets, quotes for day-ahead delivery of electricity are submitted simultaneously for all hours in the next day. The same information set is used for quoting all hours of the day. The dynamics of hourly electricity prices does not behave as a time series process. Instead, these prices should be treated as a panel in which the prices of 24 cross-sectional hours vary from day to day. This paper introduces a panel model for hourly electricity prices in day-ahead markets and examines their characteristics. The results show that hourly electricity prices exhibit hourly specific mean-reversion and that they oscillate around an hourly specific mean price level. Furthermore, a block structured cross-sectional correlation pattern between the hours is apparent.
\end{abstract}

Keywords: energy markets; day-ahead electricity electricity prices; panel models.

All errors pertain to the authors. We thank Helyette Geman, Richard Tol, participants at the EnergyForum 2005 Rotterdam Conference, the EnergyForum 2005 London Conference, the RSM Financial Management seminar and two anonymous referees for their comments. Ronald Huisman and Ronald Mahieu are at RSM Erasmus University and Energy Global. Chris Huurman is at RSM Erasmus University. The respective email addresses are: rhuisman@rsm.nl, chuurman@rsm.nl, and rmahieu@rsm.nl. 


\section{Introduction}

Since the worldwide structural reforms and market liberalization that started in the early 1990's, market places have been created, on which market participants can trade electricity forward contracts for different delivery periods. Typically, long-term contracts are traded on forward markets with delivery periods varying from a week up to a year. Short-term contracts are traded on day-ahead markets that involve delivery of electricity in the next day and on intra-day markets that involve delivery in 15 or 30 minutes after the transaction. Note that the delivery periods of these markets are complementary.

This paper focuses on the dynamics of electricity prices in day-ahead markets. Due to the nonstorability of electricity, day-ahead prices exhibit specific characteristics such as mean-reversion, seasonality, spikes and a complex time-varying volatility structure. Many of these results were obtained from examining the time series dynamics of daily average prices. An overview of the different models can be obtained from Bunn and Karakatsani (2003), Escribano, Peña and Villaplana (2002), Eydelund and Wolyniec (2003), Huisman and Mahieu (2003), Lucia and Schwartz (2002) and Pilipovic (1998).

The dynamics of daily average prices are extremely important as these prices are used as a reference price for marking to market valuations and serve as a base for option contracts such as daily callable options. However, the average prices mentioned above are indeed averages and do not meet the microstructure of the day-ahead market itself. In day-ahead markets, separate prices are quoted for delivery in each specific hour in the next day; the daily average is then the average over the 24 hours. Many markets distinguish daily average baseload and peakload prices, which refer to the average price over all 24 hours (baseload) or the average prices in the peak hours (peakload). On some markets, such as in Australia, New Zealand and the UK, prices are even quoted on a half-hourly delivery basis.

The models developed for daily average prices cannot directly be applied to describe dynamics in hourly prices. For example, if hourly prices revert to an hourly specific mean prices level, then the daily average model with a daily mean will not suffice. Other questions are whether the level of meanreversion is constant over the day or different per hour and whether the volatility structure is constant throughout the day. In addition, what is the correlation pattern between specific hours? These questions are relevant as many agents in the electricity markets are exposed to hourly variation. Power generation plants let their nomination depend on the expected prices for electricity delivery throughout the day. Companies that use electricity in a certain profile through the day that cannot be resembled by standard baseload and peakload contracts might have a demand for contracts that deliver only in a few hours of the day. To valuate these contracts market makers need to assess the expectations and risks 
for those specific hours and cannot rely on daily average prices only. Other applications can be found in power risk management, contract structuring and derivative pricing (e.g. hourly power options are currently traded in the US markets and to a lesser extent in the European markets ${ }^{1}$ ).

A few studies have recognized the need for higher frequency modeling and have addressed some interesting issues. Borenstein et. al (2002) and Saravia (2003) find a spread between day-ahead and real-time hourly prices on the U.S. power markets and attribute it to market power and speculation activity. Longstaff and Wang (2004) study the day-ahead hourly risk premium, calculated as the difference between the day-ahead price and the expected real time price. They find that premiums are affected by demand, sales and price variation. Furthermore, they study time variation in premiums by specifying a system of VAR's for each of the 24 hours in which ex-ante measures of risk (demand load and sales) are used as explanatory variables for unexpected price changes. Wolak (1997) studies the hourly price formation of the deregulated day-ahead electricity markets of England and Wales, Scandinavia, Australia and New Zealand. Wolak applies a Principal Component Analysis to the error covariance matrix obtained from a VAR hourly (or half hourly) price system to gain insight in the intra-day correlation of the errors terms. Wolak finds that the 'Anglo-Saxon' prices are difficult to forecast (i.e. 22 principal components explain $90 \%$ of variation in England and Wales data) compared to the Nordpool prices (5 principal components explain 90\% of variation). Nogales et. al (2002) use price and demand load data obtained from the Spanish and U.S. markets to forecast next-day electricity prices by time series models. Li and Flynn (2004) examine the hourly rate of price changes in fourteen deregulated markets. Knittel and Roberts (2005) fit a range of traditional financial models and less conventional electricity price models to an hourly time series of real-time Californian electricity prices, and find that forecasting performance of traditional models is poor and can be substantially improved when they address the unique electricity price features are taken into account. Ramsay and Wang (1997) and Szkuta et. al (1999) propose a neural network approach to model the dynamics of intraday prices.

Some of the studies above, model each hour separately or assume some correlation pattern between the hours. Others stack the hourly prices and treat them as a time series. An important difference between modeling daily average prices and modeling hourly prices is that hourly prices cannot be seen as a pure time series process. Time-series models assume that the information set is updated by moving from one observation to the next in time. This assumption is not valid for hourly prices, as the market microstructure does not allow for continuous trading. Many day-ahead markets are structured such that agents submit their bids and offers for delivery of electricity in all hours in the next day before a certain market closing time; hourly prices for next day delivery are determined at the same

\footnotetext{
${ }^{1}$ See Eydelund and Wolyniec for an overview on electricity option contracts.
} 
time. The information set used for setting the price of delivery in hour 23 is the same as the information set used to set the price for delivery in hour 5. Therefore, the information set is constant within the day and updates over the days. Therefore, in order to examine hourly price characteristics one cannot directly extend the time-series models that are used in some of the aforementioned studies. Applying directly a time-series approach is not sound from a methodological perspective.

This paper proposes to model hourly power prices in a panel framework. Panel models describe the dynamics of a cross-section of individuals over time. In financial literature, panel models have been applied to exchange rates for instance. Each, day news affects the prices in the FX market and has a simultaneous impact on different exchange rates. For instance, news about the U.S. economy is likely to affect all exchange rates that are denoted in terms of the U.S. Dollar. Therefore, the cross-section of U.S. Dollar denoted exchange rates behave over time and their quotes respond to the same news factors (but perhaps to a different extent) ${ }^{2}$. To model hourly prices, observe that hours can be seen as cross-sectional individuals (as their prices are quotes at the same time) whose prices change over the days. Therefore, the panel framework exactly matches the microstructure of day-ahead markets.

This paper examines the dynamics in day-ahead hourly prices using a panel model for three European wholesale power markets; the APX (the Netherlands), EEX (Germany) and PPX (France). The empirical results show that hourly electricity prices in day-ahead market mean-revert around an hourly specific mean price level, that the speed of mean-reversion is different over the hours (especially in superpeak hours) and that a block structured cross-sectional correlation pattern is apparent.

This chapter is structured as follows. Section 2 focuses on the observed characteristics of hourly electricity prices and sets out the panel methodology. Section 3 provides an overview of our dataset. Section 4 discusses the empirical results. Section 5 concludes.

\section{A panel framework for hourly prices in day-ahead markets}

As discussed above, hourly electricity prices in day-ahead markets do not follow a time series process but are in fact a panel of 24 cross-sectional hours that vary from day to day. This is due to the microstructure of many day-ahead markets prices for all hours are quoted at the same moment on a day (for instance, the Dutch APX market requires that bids and offers for each hour in the next day to be submitted before $11 \mathrm{am}$ and these prices are published around noon). A trader uses exactly the same information to set the price for hour $\mathrm{h}$ as she uses to set the price for hour $\mathrm{s}$ ( $\mathrm{h}$ being different from $\mathrm{s}$ ). Proceeding to the next day, the information set updates, but it updates simultaneously for hour 1

\footnotetext{
${ }^{2}$ See Huisman et al. (1998) for an application of a panel model to describe the dynamics of changes in exchange rates. Baltagi (1995) provides an overview of different panel model application in economics.
} 
through 24 . Therefore, hourly prices within a day behave cross-sectionally and hourly dynamics over days behave according to time-series properties.

To introduce the model, let $\mathrm{s}_{\mathrm{h}}(\mathrm{t})$ be the natural logarithm of the day-ahead price observed on day $\mathrm{t}$ for the delivery of one MW electricity in hour $h$ of the next day $t+1$. Following Lucia and Schwartz (2002) and Huisman and Mahieu (2003), the day-ahead price is the sum of two independent components: a deterministic component $\mathrm{f}_{\mathrm{h}}(\mathrm{t})$ and a stochastic component $\mathrm{x}_{\mathrm{h}}(\mathrm{t})$ :

(1) $s_{h}(t)=f_{h}(t)+x_{h}(t)$

The deterministic component $\mathrm{f}_{\mathrm{h}}(\mathrm{t})$ accounts for predictable regularities, such as mean price levels and seasonal behaviour. The deterministic component consists of a mean price level $\mu_{0}$ and hourly deviations from the mean price level to allow for differences in mean price levels over the hours, $\mu_{\mathrm{h}}$ for $\mathrm{h}=1 \ldots 23$ ( $\mu_{24}$ equals 0 to prevent from multicollinearity). The deterministic component also allows for different price levels for different weekdays of the week. To model this, $I^{\mathrm{d}}(\mathrm{t})$ is a dummy variable that equals 1 if the delivery day $t+1$ is a weekday $d(d=1$ corresponds with Saturday, $d=2$ corresponds with a Sunday, ..., $d=7$ corresponds with a Friday), and let $\beta_{d}$ be the difference from the mean price level ( $\beta_{7}$ equals 0 to prevent from multicollinearity). The expression for the deterministic component becomes:

(2) $\mathrm{f}_{\mathrm{h}}(\mathrm{t})=\mu_{0}+\mu_{\mathrm{h}}+\Sigma_{\mathrm{d}} \beta_{\mathrm{d}} \mathrm{I}^{\mathrm{d}}(\mathrm{t})$

The stochastic component in equation (1) accounts for the variation of the price around the deterministic component. The stochastic part may account stochastic characteristics such as meanreversion, time-varying volatility and spikes. In this paper, the stochastic component is a meanreverting process. To model this, let $\alpha_{h}$ be the rate of mean-reversion for hour $h$. It reflects the speed with which the price moves back to its hourly fundamental component when the price deviated from that value yesterday. The expression for the stochastic component becomes:

(3) $\mathrm{x}_{\mathrm{h}}(\mathrm{t})=-\alpha_{\mathrm{h}} \mathrm{x}_{\mathrm{h}}(\mathrm{t}-1)+\varepsilon_{\mathrm{h}}(\mathrm{t})$.

In equation (3), $\varepsilon_{\mathrm{h}}(\mathrm{t})$ is the error term. The equations (2) and (3) reveal the combination of crosssectional variation and time-series dynamics in panel framework. The price for delivery in hour $\mathrm{h}$ in day $t$ depends on the price for that hour in the previous day and not on the price in the previous hour.

The error term in equation (3), $\varepsilon_{\mathrm{h}}(\mathrm{t})$, is assumed to be independent over the days but it allows for crosssectional covariance between the hours. Allowing for cross-sectional correlation is important, as when a trader submits her quote delivery in hour $\mathrm{h}$ in the next day, she will let this quote depend on the information she has for all other hours observed at the time of quotation. Let $\varepsilon(t)$ be the $(24 \times 1)$ vector 
containing the hourly error $\varepsilon_{\mathrm{h}}(\mathrm{t})$ in row h and let $\boldsymbol{\Sigma}$ be the (24 x 24) hourly cross sectional covariance matrix $(\mathrm{h}=1$ through 24$)$ :

(4) $\varepsilon(\mathrm{t}) \sim \operatorname{IID}(0, \Sigma)$.

Equation (4) shows that one can disentangle cross-sectional dependence from time-series dependence. The covariance matrix $\Sigma$ can be specified. In this paper, the covariance matrix is not specified in order to examine the cross-sectional patterns that are embedded in the prices. The parameters in the model are estimated using the seemingly unrelated regressions (SUR) method. SUR estimates the parameters of the 24 hourly time series, accounting for heteroskedasticity and contemporaneaous correlations in the errors across the time series. We refer to Baltagi (1995) for an overview of panel models and their applications and for details on SUR.

\section{Data}

The dataset consists of the hourly day-ahead electricity price for three markets in 2004, the Amsterdam Power Exchange (APX), the European Energy Exchange (EEX; Germany) and the Paris Power Exchange (PPX), having 8760 (24 hours time 365 days) observations for each market. Table 1 shows summary statistics for the dataset. The table shows the typical characteristics of day-ahead electricity prices: high volatility, skewness, and excess kurtosis.

Table 1: Summary statistics of the day-ahead prices for 2004 ( 8760 observations for each market).

\begin{tabular}{|l|cccccc|}
\cline { 2 - 7 } \multicolumn{1}{c|}{} & \multicolumn{2}{c}{ APX } & \multicolumn{2}{c}{ EEX } & \multicolumn{2}{c|}{ PPX } \\
\cline { 4 - 7 } \multicolumn{1}{c|}{} & Price & Log price & Price & Log price & Price & Log price \\
\hline Mean & 31.58 & 3.315 & 28.52 & 3.261 & 28.13 & 3.251 \\
St. deviation & 28.70 & 3.357 & 28.17 & 3.338 & 28.01 & 3.333 \\
Minimum & 22.26 & 0.563 & 10.80 & 0.470 & 10.41 & 0.459 \\
Maximum & 0.010 & -4.605 & 0.450 & -0.799 & 0.000 & -3.219 \\
Skewness & 800.0 & 6.685 & 150.0 & 5.010 & 100.0 & 4.605 \\
Excess kurtosis & 10.46 & -2.717 & 0.502 & -1.609 & 0.210 & -1.834 \\
& 239.1 & 36.10 & 6.236 & 8.022 & 13.90 & 3.567 \\
\hline
\end{tabular}

\section{Empirical results}

Table 2 contains the SUR estimates for the parameters in equations (2), (3) and (4). Analyzing the deterministic components first, both $\beta_{1}$ and $\beta_{2}$ are significantly negative for all markets indicating the lower prices for electricity delivered on weekend days. The average mean log price level $\mu_{0}$ varies between 3.236 (€25.43) for the EEX and 3.300 (€27.11) for the PPX. The estimates for $\mu_{1}$ through $\mu_{23}$ reflect the hourly deviations from the mean price level. The estimates for $\mu_{\mathrm{h}}$ are negative for hours 1 
through 7 (also for hour 8 on the APX) indicating the lower than daily average prices for off-peak delivery of power. Prices then increase for later hours and decrease late in the evening. These estimates make sense as demand for power is low in weekend and off-peak hours on weekdays and high in peak hours.

The estimates for the mean-reversion parameters $\alpha_{\mathrm{h}}$ show some differences over the hours. The estimates are in the range of 0.7 and 0.9 until hour 17 and then fall to values in the range of 0.4 and 0.6 for the hours 18 through 22 . The estimates then assume the values of the morning hours at hour 23 and 24. Clearly, mean-reversion is not stable over the day; super-peak hours (18 through 22) exhibit significant less mean-reversion. This can be explained by the higher demand for power in these hours resulting in less reserve production capacity and therefore an increased probability of shortages and spikes. Prices in these hours are less predictable. This result is important. Forward and options contracts in the super-peak hours should not be valuated based on models that use data for baseload and/or peakload forward contracts as those prices will overestimate the true amount of meanreversion. In nomination schemes, one should be careful assuming any price dependencies in the superpeak hours. Mean-reversion is not constant throughout the day. The level of mean-reversion is significantly lower in the super peak hours. The reported $\mathrm{R}^{2}$ s are all higher than 0.94 and the Durbon Watson statistics show no evidence for serial correlations. 
Table 2: SUR parameter estimates for the general model (standard errors are in parenthesis).

\begin{tabular}{|c|c|c|c|c|c|c|c|c|c|c|c|}
\hline & APX & EEX & PPX & & APX & EEX & PPX & & APX & EEX & PPX \\
\hline$\mu_{0}$ & $\begin{array}{c}3.290 \\
(0.020)\end{array}$ & $\begin{array}{c}3.236 \\
(0.020)\end{array}$ & $\begin{array}{l}3.300 \\
(0.020)\end{array}$ & $\mu_{19}$ & $\begin{array}{c}0.340 \\
(0.026)\end{array}$ & $\begin{array}{c}0.321 \\
(0.016)\end{array}$ & $\begin{array}{c}0.274 \\
(0.016)\end{array}$ & $\alpha_{15}$ & $\begin{array}{c}0.770 \\
(0.024)\end{array}$ & $\begin{array}{c}0.776 \\
(0.018)\end{array}$ & $\begin{array}{c}0.753 \\
(0.020)\end{array}$ \\
\hline$\mu_{1}$ & $\begin{array}{l}-0.134 \\
(0.011)\end{array}$ & $\begin{array}{l}-0.111 \\
(0.016)\end{array}$ & $\begin{array}{l}-0.196 \\
(0.015)\end{array}$ & $\mu_{20}$ & $\begin{array}{c}0.283 \\
(0.020)\end{array}$ & $\begin{array}{c}0.293 \\
(0.014)\end{array}$ & $\begin{array}{c}0.263 \\
(0.013)\end{array}$ & $\alpha_{16}$ & $\begin{array}{c}0.771 \\
(0.024)\end{array}$ & $\begin{array}{c}0.774 \\
(0.018)\end{array}$ & $\begin{array}{c}0.804 \\
(0.022)\end{array}$ \\
\hline$\mu_{2}$ & $\begin{array}{l}-0.342 \\
(0.017)\end{array}$ & $\begin{array}{l}-0.316 \\
(0.021)\end{array}$ & $\begin{array}{l}-0.322 \\
(0.019)\end{array}$ & $\mu_{21}$ & $\begin{array}{c}0.221 \\
(0.016)\end{array}$ & $\begin{array}{c}0.264 \\
(0.014)\end{array}$ & $\begin{array}{c}0.187 \\
(0.010)\end{array}$ & $\alpha_{17}$ & $\begin{array}{c}0.650 \\
(0.029)\end{array}$ & $\begin{array}{c}0.721 \\
(0.020)\end{array}$ & $\begin{array}{c}0.758 \\
(0.025)\end{array}$ \\
\hline$\mu_{3}$ & $\begin{array}{l}-0.471 \\
(0.020)\end{array}$ & $\begin{array}{l}-0.448 \\
(0.027),\end{array}$ & $\begin{array}{l}-0.429 \\
(0.021)\end{array}$ & $\mu_{22}$ & $\begin{array}{c}0.144 \\
(0.010)\end{array}$ & $\begin{array}{c}0.196 \\
(0.012)\end{array}$ & $\begin{array}{c}0.134 \\
(0.009)\end{array}$ & $\alpha_{18}$ & $\begin{array}{c}0.441 \\
(0.029)\end{array}$ & $\begin{array}{c}0.601 \\
(0.022)\end{array}$ & $\begin{array}{c}0.614 \\
(0.022)\end{array}$ \\
\hline$\mu_{4}$ & $\begin{array}{l}-0.572 \\
(0.024)\end{array}$ & $\begin{array}{l}-0.535 \\
(0.029),\end{array}$ & $\begin{array}{l}-0.566 \\
(0.023)\end{array}$ & $\mu_{23}$ & $\begin{array}{c}0.100 \\
(0.009)\end{array}$ & $\begin{array}{c}0.153 \\
(0.008)\end{array}$ & $\begin{array}{c}0.096 \\
(0.006)\end{array}$ & $\alpha_{19}$ & $\begin{array}{c}0.446 \\
(0.028)\end{array}$ & $\begin{array}{c}0.541 \\
(0.022)\end{array}$ & $\begin{array}{c}0.479 \\
(0.021)\end{array}$ \\
\hline$\mu_{5}$ & $\begin{array}{l}-0.573 \\
(0.023)\end{array}$ & $\begin{array}{l}-0.501 \\
(0.027)\end{array}$ & $\begin{array}{l}-0.684 \\
(0.033)\end{array}$ & $\alpha_{1}$ & $\begin{array}{c}0.787 \\
(0.025)\end{array}$ & $\begin{array}{c}0.832 \\
(0.030)\end{array}$ & $\begin{array}{c}0.779 \\
(0.027)\end{array}$ & $\alpha_{20}$ & $\begin{array}{c}0.487 \\
(0.026)\end{array}$ & $\begin{array}{c}0.536 \\
(0.023)\end{array}$ & $\begin{array}{c}0.436 \\
(0.020)\end{array}$ \\
\hline$\mu_{6}$ & $\begin{array}{l}-0.410 \\
(0.033)\end{array}$ & $\begin{array}{l}-0.267 \\
(0.025)\end{array}$ & $\begin{array}{l}-0.404 \\
(0.023)\end{array}$ & $\alpha_{2}$ & $\begin{array}{c}0.778 \\
(0.024)\end{array}$ & $\begin{array}{c}0.811 \\
(0.026)\end{array}$ & $\begin{array}{c}0.761 \\
(0.024)\end{array}$ & $\alpha_{21}$ & $\begin{array}{c}0.509 \\
(0.028)\end{array}$ & $\begin{array}{c}0.599 \\
(0.023)\end{array}$ & $\begin{array}{c}0.546 \\
(0.020)\end{array}$ \\
\hline$\mu_{7}$ & $\begin{array}{l}-0.288 \\
(0.045)\end{array}$ & $\begin{array}{l}-0.132 \\
(0.030)\end{array}$ & $\begin{array}{l}-0.241 \\
(0.034)\end{array}$ & $\alpha_{3}$ & $\begin{array}{c}0.745 \\
(0.023)\end{array}$ & $\begin{array}{c}0.757 \\
(0.025)\end{array}$ & $\begin{array}{c}0.699 \\
(0.023)\end{array}$ & $\alpha_{22}$ & $\begin{array}{c}0.633 \\
(0.028)\end{array}$ & $\begin{array}{c}0.651 \\
(0.022)\end{array}$ & $\begin{array}{c}0.600 \\
(0.022)\end{array}$ \\
\hline$\mu_{8}$ & $\begin{array}{l}-0.054 \\
(0.051)\end{array}$ & $\begin{array}{c}0.118 \\
(0.029)\end{array}$ & $\begin{array}{c}0.011 \\
(0.027)\end{array}$ & $\alpha_{4}$ & $\begin{array}{c}0.820 \\
(0.027)\end{array}$ & $\begin{array}{c}0.744 \\
(0.024)\end{array}$ & $\begin{array}{c}0.659 \\
(0.024)\end{array}$ & $\alpha_{23}$ & $\begin{array}{c}0.818 \\
(0.031)\end{array}$ & $\begin{array}{c}0.712 \\
(0.025)\end{array}$ & $\begin{array}{c}0.641 \\
(0.022)\end{array}$ \\
\hline$\mu_{9}$ & $\begin{array}{c}0.189 \\
(0.029)\end{array}$ & $\begin{array}{c}0.231 \\
(0.026)\end{array}$ & $\begin{array}{c}0.169 \\
(0.024)\end{array}$ & $\alpha_{5}$ & $\begin{array}{c}0.781 \\
(0.023)\end{array}$ & $\begin{array}{c}0.708 \\
(0.025)\end{array}$ & $\begin{array}{c}0.666 \\
(0.025)\end{array}$ & $\alpha_{24}$ & $\begin{array}{c}0.742 \\
(0.028)\end{array}$ & $\begin{array}{c}0.787 \\
(0.031)\end{array}$ & $\begin{array}{c}0.715 \\
(0.023)\end{array}$ \\
\hline$\mu_{10}$ & $\begin{array}{c}0.368 \\
(0.024)\end{array}$ & $\begin{array}{c}0.326 \\
(0.018)\end{array}$ & $\begin{array}{c}0.265 \\
(0.017)\end{array}$ & $\alpha_{6}$ & $\begin{array}{c}0.854 \\
(0.034)\end{array}$ & $\begin{array}{c}0.784 \\
(0.028)\end{array}$ & $\begin{array}{c}0.773 \\
(0.027)\end{array}$ & $\beta_{1}$ & $\begin{array}{l}-0.171 \\
(0.020)\end{array}$ & $\begin{array}{l}-0.209 \\
(0.019)\end{array}$ & $\begin{array}{l}-0.226 \\
(0.020)\end{array}$ \\
\hline$\mu_{11}$ & $\begin{array}{c}0.458 \\
(0.024)\end{array}$ & $\begin{array}{c}0.384 \\
(0.016)\end{array}$ & $\begin{array}{c}0.312 \\
(0.015)\end{array}$ & $\alpha_{7}$ & $\begin{array}{c}0.941 \\
(0.028)\end{array}$ & $\begin{array}{c}0.830 \\
(0.023)\end{array}$ & $\begin{array}{c}0.808 \\
(0.029)\end{array}$ & $\beta_{2}$ & $\begin{array}{l}-0.359 \\
(0.023)\end{array}$ & $\begin{array}{l}-0.356 \\
(0.022)\end{array}$ & $\begin{array}{l}-0.403 \\
(0.024)\end{array}$ \\
\hline$\mu_{12}$ & $\begin{array}{c}0.530 \\
(0.025)\end{array}$ & $\begin{array}{c}0.469 \\
(0.018)\end{array}$ & $\begin{array}{c}0.364 \\
(0.0315)\end{array}$ & $\alpha_{8}$ & $\begin{array}{c}0.931 \\
(0.028)\end{array}$ & $\begin{array}{c}0.867 \\
(0.023)\end{array}$ & $\begin{array}{c}0.790 \\
(0.023)\end{array}$ & $\beta_{3}$ & $\begin{array}{c}0.031 \\
(0.024)\end{array}$ & $\begin{array}{l}-0.001 \\
(0.022)\end{array}$ & $\begin{array}{l}-0.048 \\
(0.025)\end{array}$ \\
\hline$\mu_{13}$ & $\begin{array}{c}0.382 \\
(0.017)\end{array}$ & $\begin{array}{c}0.378 \\
(0.015)\end{array}$ & $\begin{array}{c}0.319 \\
(0.013)\end{array}$ & $\alpha_{9}$ & $\begin{array}{c}0.869 \\
(0.023)\end{array}$ & $\begin{array}{c}0.841 \\
(0.021)\end{array}$ & $\begin{array}{c}0.865 \\
(0.021)\end{array}$ & $\beta_{4}$ & $\begin{array}{c}0.084 \\
(0.023)\end{array}$ & $\begin{array}{c}0.039 \\
(0.022)\end{array}$ & $\begin{array}{c}0.051 \\
(0.024)\end{array}$ \\
\hline$\mu_{14}$ & $\begin{array}{c}0.367 \\
(0.020)\end{array}$ & $\begin{array}{c}0.337 \\
(0.017)\end{array}$ & $\begin{array}{c}0.282 \\
(0.013)\end{array}$ & $\alpha_{10}$ & $\begin{array}{c}0.832 \\
(0.025)\end{array}$ & $\begin{array}{c}0.829 \\
(0.018)\end{array}$ & $\begin{array}{c}0.800 \\
(0.019)\end{array}$ & $\beta_{5}$ & $\begin{array}{c}0.063 \\
(0.023)\end{array}$ & $\begin{array}{c}0.038 \\
(0.021)\end{array}$ & $\begin{array}{c}0.046 \\
(0.023)\end{array}$ \\
\hline$\mu_{15}$ & $\begin{array}{c}0.283 \\
(0.020)\end{array}$ & $\begin{array}{c}0.269 \\
(0.018)\end{array}$ & $\begin{array}{c}0.223 \\
(0.014)\end{array}$ & $\alpha_{11}$ & $\begin{array}{c}0.770 \\
(0.024)\end{array}$ & $\begin{array}{c}0.814 \\
(0.018)\end{array}$ & $\begin{array}{c}0.773 \\
(0.020)\end{array}$ & $\beta_{6}$ & $\begin{array}{c}0.062 \\
(0.020)\end{array}$ & $\begin{array}{c}0.069 \\
(0.019)\end{array}$ & $\begin{array}{c}0.045 \\
(0.020)\end{array}$ \\
\hline$\mu_{16}$ & $\begin{array}{c}0.220 \\
(0.020)\end{array}$ & $\begin{array}{c}0.219 \\
(0.018)\end{array}$ & $\begin{array}{c}0.170 \\
(0.016)\end{array}$ & $\alpha_{12}$ & $\begin{array}{c}0.703 \\
(0.026)\end{array}$ & $\begin{array}{c}0.693 \\
(0.024)\end{array}$ & $\begin{array}{c}0.700 \\
(0.022)\end{array}$ & Adj. $R^{2}$ & 0.941 & 0.955 & 0.942 \\
\hline$\mu_{17}$ & $\begin{array}{c}0.208 \\
(0.023)\end{array}$ & $\begin{array}{c}0.208 \\
(0.018)\end{array}$ & $\begin{array}{c}0.154 \\
(0.018)\end{array}$ & $\alpha_{13}$ & $\begin{array}{c}0.766 \\
(0.026)\end{array}$ & $\begin{array}{c}0.741 \\
(0.020)\end{array}$ & $\begin{array}{c}0.702 \\
(0.021)\end{array}$ & $\begin{array}{l}\text { Durbin } \\
\text { Watson }\end{array}$ & 2.060 & 2.052 & 2.065 \\
\hline$\mu_{18}$ & $\begin{array}{c}0.428 \\
(0.049)\end{array}$ & $\begin{array}{c}0.274 \\
(0.018)\end{array}$ & $\begin{array}{c}0.216 \\
(0.016)\end{array}$ & $\alpha_{14}$ & $\begin{array}{c}0.811 \\
(0.023)\end{array}$ & $\begin{array}{c}0.805 \\
(0.021)\end{array}$ & $\begin{array}{c}0.749 \\
(0.019)\end{array}$ & Log-LH & -8645.5 & -8331.0 & -8239.5 \\
\hline
\end{tabular}


Other interesting observations on hourly stochastic patterns show up in the cross-sectional correlation matrix of the error term as specified in equation (4). These estimates are listed in Table 3 for the EEX. The results for the other markers are not shown here, but show patterns similar to the EEX.

In table 3 , the correlation numbers bigger than 0.5 are reported bold faced; non-significant correlations are left blank. Table 3 shows evidence for a clear cross-sectional correlation structure in hourly electricity prices. Firstly, observe the high correlations numbers ranging between 0.732 (between hour 20 and 21) and 0.964 (between hour 15 and 16) between two adjacent hours. An explanation for this effect is that consumption and capacity flows over the hours; if reserve capacity is low in one hour it will probably be low in the next hour as well and if demand is high in one hour it will probably be high in the next hour as well. Secondly, observe the block-structure of correlations. The first block is identified by the hours 1 through 6 and hour 24. Prices in these off-peak hours exhibit high crosssectional correlations. The second block shows up in the peak hours from hour 6 through hour 19 . Again prices in these hours are highly correlated. There is evidence for a clear peak off-peak correlation structure but, interestingly, the boundaries of the peak block do not perfectly match the market definitions of peak hours (hours 7 through 23).

The empirical results from the panel model show that hourly electricity prices in day-ahead market mean-revert around an hourly specific mean price level, that the speed of mean-reversion is different over the hours (especially in superpeak hours) and that a block structured cross-sectional correlation pattern is apparent. 


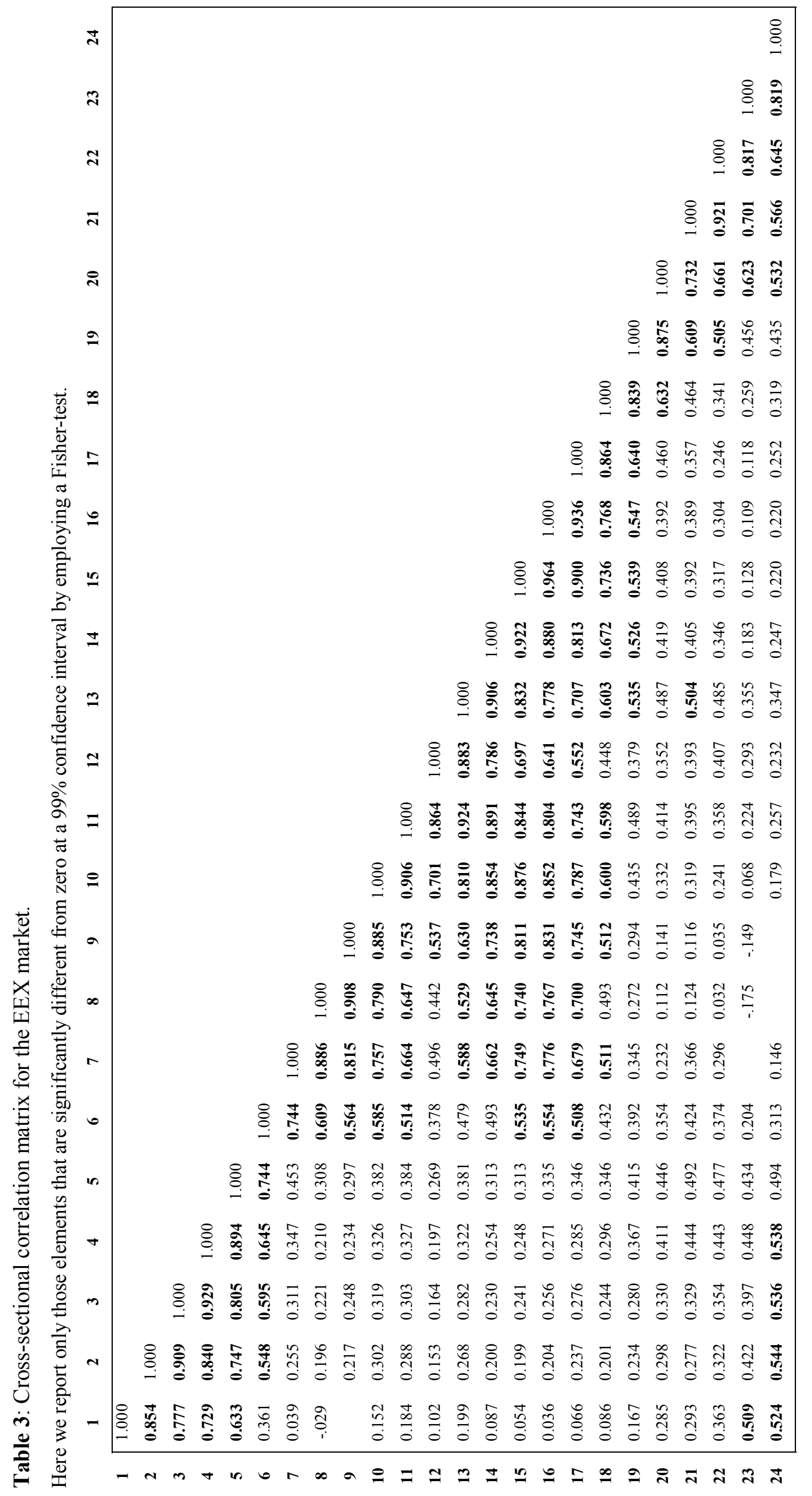




\section{Concluding remarks}

This paper proposes a panel framework to model the dynamics in hourly electricity prices in dayahead markets. Hourly electricity prices do not follow a time series process but are in fact a panel of 24 cross-sectional hours that vary from day to day. This is due to the microstructure of many dayahead markets prices for all hours are quoted at the same moment on a day.

The empirical results show that hourly electricity prices in day-ahead market mean-revert around an hourly specific mean price level, that the speed of mean-reversion is different over the hours (especially in superpeak hours) and that a block structured cross-sectional correlation pattern is apparent. Prices in peak-hours correlate highly among each other and the same holds for prices in offpeak hours. There is much less correlation between peak and off-peak hours. This effect can be explained by the differences in reserve capacity between the two blocks. The lower reserve capacity in the peak hours implies that the prices in those hours are more volatile and exhibit more spikes than prices in off-peak hours.

Understanding the characteristics of hourly electricity prices is important as many agents in the electricity markets are exposed to hourly variation. Power generation plants let their nomination depend on the expected prices for electricity delivery throughout the day. Companies that use electricity in a certain profile through the day that cannot be resembled by standard baseload and peakload contracts might have a demand for contracts that deliver only in a few hours of the day. To valuate these contracts market makers need to assess the expectations and risks for those specific hours and cannot rely on daily average prices only. Other applications can be found in power risk management, contract structuring and derivative pricing (e.g. hourly power options are currently traded in the US markets and to a lesser extent in the European markets).

\section{References}

Baltagi, B.H., 1995, Econometric Analysis of Panel Data, Wiley Publishers New York.

Borenstein, S., Bushnell, J., Knittel, C. and Wolfram, C., 2002, Trading Inefficiencies in California's Electricity Market, Working Paper PWP-086, University of California Energy Institute, Berkeley.

Bunn, D.W. and N. Karakatsani, 2003, Forecasting Electricity Prices, London Business School Working Paper. 
Escribano, A., Peña, J. and Villapana, P., 2002, Modeling Electricity Prices: International Evidence, Working Paper 02-27, Universidad Carlos III de Madris

Eydeland, A. and K. Wolyniec, 2003, Energy and Power Risk Management; New Developments in Modeling, Pricing and Hedging, John Wiley \& Sons, Hoboken (New Jersey).

Huisman, R., K. Koedijk, C. Kool, and F. Nissen, 1998, Extreme Support for Uncovered Interest Parity, Journal of International Money and Finance, 17, 211-228.

Huisman, R. and R. Mahieu, 2003, Regime Jumps in Electricity Prices, Energy Economics, 25, 425434.

Li, Y and Flynn, P., Deregulated Power Prices: Comparison of Volatility, Energy Policy, 32, pp. 15911601.

Longstaff, F. and Wang, A., 2004, A High-Frequency Empirical Analysis, Journal of Finance, 59 (4), pp.1887-1900.

Lucia, J. and E.S. Schwartz, 2002, Electricity Prices and Power Derivatives: Evidence from the Nordic Power Exchange, Review of Derivatives Research, 5, 5-50.

Nogales, F. Contreras, J., Conejo, A. and Espinola, R., 2002, Forecasting Next-Day Electricity Prices by Time Series Models, IEEE Transactions on Power Systems, 17 (2), pp. 342-348.

Pilipovic, D. (1998), Energy Risk: Valuing and Managing Energy Derivatives, McGraw Hill, New York.

Ramsay, B. and Wang, A., A Neural Network Based Estimator for Electricity Spot Pricing with Particular Reference to Weekends and Public Holidays, Neurocomputing, 23 (1) pp. 47-57.

Saravia, C., 2003, Speculative Trading and Market Performance: the Effect of Arbitrageurs on Efficiency in the New York Electricity Market, Working Paper, University of California Energy Institute, Berkeley.

Szkuta, B., Sanabria, L. and Dillon, T. Electricity Price Short-term Forecasting Using Artificial Networks, IEEE Transactions on Power Systems, 4. pp. 851-857. 
Wolak, F., 1997, Market Design and Price Behavior in Restructured Electricity Markets: An International Comparison, Working Paper, Department of Economics Stanford University. 


\section{Publications in the Report Series Research ${ }^{*}$ in Management}

\section{ERIM Research Program: "Finance and Accounting"}

\section{7}

Revisiting Uncovered Interest Rate Parity: Switching Between UIP and the Random Walk Ronald Huisman and Ronald Mahieu ERS-2007-001-F\&A

Hourly Electricity Prices in Day-Ahead Markets

Ronald Huisman, Christian Huurman and Ronald Mahieu ERS-2007-002-F\&A

\footnotetext{
A complete overview of the ERIM Report Series Research in Management: https://ep.eur.nl/handle/1765/1

ERIM Research Programs:

LIS Business Processes, Logistics and Information Systems

ORG Organizing for Performance

MKT Marketing

F\&A Finance and Accounting

STR Strategy and Entrepreneurship
} 